Acta Technologica Agriculturae 2

Nitra, Slovaca Universitas Agriculturae Nitriae, 2015, pp. 54-56

\title{
STUDY OF INJECTION PROCESS CAPABILITY IN PRODUCTION OF PLASTIC BOXES
}

\author{
Katarína LESTYÁNSZKA ŠKŮRKOVÁ*, Jozefína KUDIČOVÁ \\ Slovak University of Technology in Bratislava, Slovak Republic
}

\begin{abstract}
Ensuring the process capability currently means the warranty that produced products will be in accordance with requirements, both on the company's as well as customer's side. This study focuses on the statistical control of injection process capability in serial production in a company focusing on products for healthcare. The injection process is evaluated by control charts, specifically by control chart for average and range $(\bar{x}, R)$. As the results showed, based on the chart for average and range, we are able to say that the injection process is under statistical control. The requirement for process capability was met; the indices of process capability $C_{p}$ and $C_{p k}$ are higher than the determined value 1.33. The normality of measured values was verified by histogram. The obtained values are: $C_{p}=1.85$ and $C_{p k}=1.82$. Therefore, we may consider the process as capable.
\end{abstract}

Keywords: control charts, stability, normality, $C_{p}$ and $C_{p k}$ indices, statistical control

Nowadays, it is necessary not only to produce high-quality products for the satisfaction of customers but there is also a need to pay attention to the modernization of production processes in organizations (Prístavka, 2013). The introduction of the quality management system is a way towards certification ensuring the competitiveness of organization and its position in the market in terms of customer (Prístavka, 2014). The process capability means the process ability to permanently achieve defined quality criterions and also the ability to work with some accuracy. The process capability evaluation is today often required by customer, because it is an evidence for them that the product was made in stable production conditions where required quality criterions were regularly ensured. This is also information about the fact what accuracy can count be in the future with. For producer, it is very important information that enables the choice of suitable machine for producing some products, estimate the risks of nonconforming products, and to plan the preventive and corrective actions for improvement (Kučerová, 2011).

The capability analysis of measures, production equipment and process is active in the application, development and permanent improvement of quality system effectiveness (Korenko et al., 2013). The purpose of statistical process control is to determine whether every significant causes of process instability were removed. It is required that the mean value of the monitored quality attribute and its variability are constant in time. The best way to find this information is by using the Shewhart control charts, and it represents the preparatory stage of statistical regulation (Hrubec, 2001).

The starting point for statistical regulation is to well manage the production processes. The production process is considered as well managed if it is affected by random causes only. If there is a large number of random causes in a process, resulting distribution can be characterized as normal.

Currently, we evaluate the process capability by process capability indices $C_{p}$ (characterizes the process dispersion) and $C_{p k}$ (characterizes the process location in the tolerance area). The process may be considered as capable if the values of indices $C_{p}$ and $C_{p k}$ are higher than 1.33 (Hrubec, 2009).

Input data include:

- production conditions of serial production,

- capable measuring equipment,

- capable production equipment,

- process is statistically controlled (stable),

- measured values from the process are characterized by normal distribution,

- technical and other specifications are defined by customer requirements,

- nominal value is located in the centre of tolerance range.

Using this method, it is necessary to take into account and to apply this information and findings from previous process observation (Hrubec, 2001).

\section{Material and methods}

\section{Process description}

Working operation: injection

Attribute: box weight

Nominal value: $16^{ \pm 0.1} \mathrm{~g}$

Lower specification limit (LSL): $15.9 \mathrm{~g}$ 
Upper specification limit (USL): $16.1 \mathrm{~g}$

Measuring equipment: scale KERN

Number of measurements: $N=150$

Subgroup size: $n=5$

Sampling interval: every day in one month

Number of subgroups: $k=50$

The organization is situated in Eastern Slovakia and deals with manufacturing plastic products for healthcare using the plastic injection method. This article focuses on the statistical evaluation of the injection process in the production of plastic boxes in connection with the statistical regulation of the process. The criterions for capability evaluation are the indices $C_{p}$ and $C_{p k}$. In terms of product specification, the weight of boxes $16^{ \pm 0.1} \mathrm{~g}$ is considered as the critical attribute. The weight of boxes was measured by the scale KERN. The scale capability was verified, and the scale was considered as capable. The normal distribution of measured values will be evaluated by histogram. In the statistical regulation of the plastic injection process, the Shewhart control chart for average and range $(\bar{x}, R)$ will be used.

The measured values are used for the calculation of the following.

Average value of attribute in subgroup:

$$
\overline{X_{i}}=\frac{1}{n} \sum_{j=1}^{n} X_{i j}
$$

for $i=1,2 \ldots k$ and for $j=1,2 \ldots n$

where:

$i \quad$ - sequential number of subgroup

$j \quad$ - sequential number of measured value in subgroup

$k \quad$ - number of subgroups

$n \quad$ - subgroup size

$X_{i j} \quad$ - measured value in the $i$-th subgroup

Range in subgroup:

$$
R_{i}=\operatorname{MAX}\left(X_{i j}\right)-\operatorname{MIN}\left(X_{i j}\right)
$$

for $i=1,2 \ldots k$ and for $j=1,2 \ldots n$

where:

$\operatorname{MAX}\left(X_{i j}\right)$ and $\operatorname{MIN}\left(X_{i j}\right)$ - the maximum and minimum value measured in the $i$-th subgroup

Average of process:

$$
\overline{\bar{X}}=\frac{1}{k} \sum_{i=1}^{k} \overline{X_{i}}
$$

Average range:

$$
\bar{R}=\frac{1}{k} \sum_{i=1}^{k} R_{i}
$$

where:

$R_{i} X_{i}$ - ranges and averages in the $i$-th subgroups $(i=1,2 \ldots$

k). $\bar{R}$ and $\overline{\bar{X}}$ in control charts form central lines $(C L)$

Calculation of control limits:

Upper and lower control limits for range and average:

$$
U C L_{R}=D_{4} \times \bar{R}
$$

$$
\begin{gathered}
L C L_{R}=D_{3} \times \bar{R} \\
U C L_{\bar{X}}=\overline{\bar{X}}+A_{2} \times \bar{R} \\
L C L_{\bar{X}}=\overline{\bar{X}}-A_{2} \times \bar{R}
\end{gathered}
$$

where:

$D_{4}, D_{3}$ and $A_{2}$ - the constants of control limits; they are changing depending on subgroup size $n$ (in our case $n=5)$, the values: $D_{3}=0.000, D_{4}=2.114$ and $A_{2}=0.577$

The process capability indices:

Process capability index $C_{p}$ :

$$
C_{p}=\frac{U S L-L S L}{6 \times \hat{\sigma}}=\frac{T}{6 \times \hat{\sigma}}
$$

Corrected process capability index $C_{p k}$ :

$$
\begin{gathered}
C_{P K}=\frac{U S L-\overline{\bar{X}}}{3 \times \hat{\sigma}} \\
C_{P K}=\frac{\overline{\bar{X}}-L S L}{3 \times \hat{\sigma}}
\end{gathered}
$$

where:

USL, LSL - upper and lower specification limits

$T \quad$ - tolerance of attribute

$\hat{\sigma} \quad-\quad$ estimation of process standard deviation

The following condition shall apply: $C_{p} \geq 1.33$ and $C_{p k} \geq 1.33$ (whereby the lower value of $C_{p k}$ is accepted) (Hrubec, 2014).

\section{Results and discussion}

In the injection process in the production of plastic boxes, we have measured the values for 50 subgroups. Calculated characteristics for average $\bar{x}$ and range $R$ are used for plotting the control charts.

The following control limits are valid for $(\bar{X}, R)$ control charts:

$$
\begin{gathered}
U C L_{X}=16.022 \\
U C L_{R}=0.085 \\
L C L_{X}=15.975 \\
L C L_{R}=\text { not defined } \\
C L_{X}=15.998 \\
C L_{R}=0.04
\end{gathered}
$$

The resulting average of measurements, i.e. the process ability to hold the target value $T=16 \mathrm{~g}$, is well above the required limit. The central limits have not been exceeded. On the basis of these results, as can be seen in Figure 1 for range $R$ and in Figure 2 for average $\bar{X}$, we can consider the process as stable. Normal distribution was confirmed by histogram, as can be seen in Figure 3. Subsequently, the process capability indices $C_{p}$ and $C_{p k}$ are calculated. 
The data necessary for the process capability indices calculation:

$$
\begin{gathered}
\sigma=0.017998 \\
\mu=15.998
\end{gathered}
$$

Obtained values: $C_{p}=1.85$ and $C_{p k}=1.82$.

Based on the process capability evaluation, we can state that the values $C_{p}=1.85$ and $C_{p k}=1.82$ are higher than 1.33; therefore, the injection process in the production of plastic boxes is currently sustainable, and there is a place to continue in its further improvement.

This method was also used in evaluation of the assembly process capability study of automotive seats (Andrássyová et al., 2011). The process was also controlled by the control

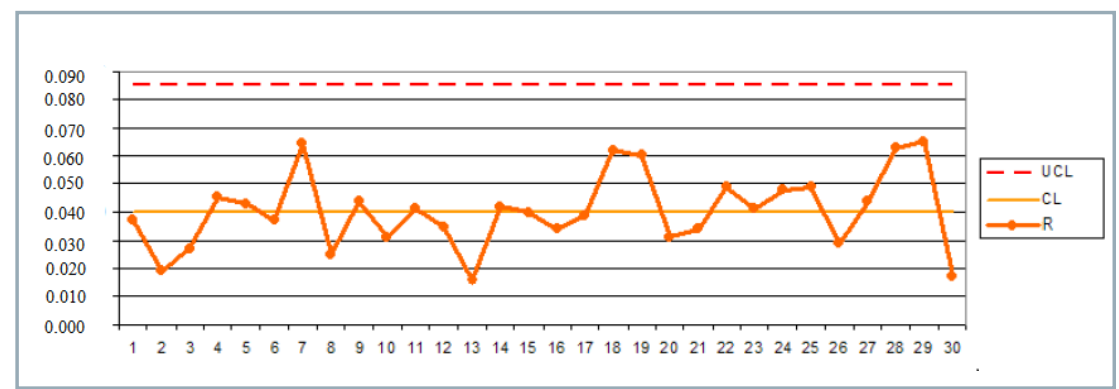

Figure 1 Control chart for range $\mathrm{R}$

Source: Kudičová, 2012

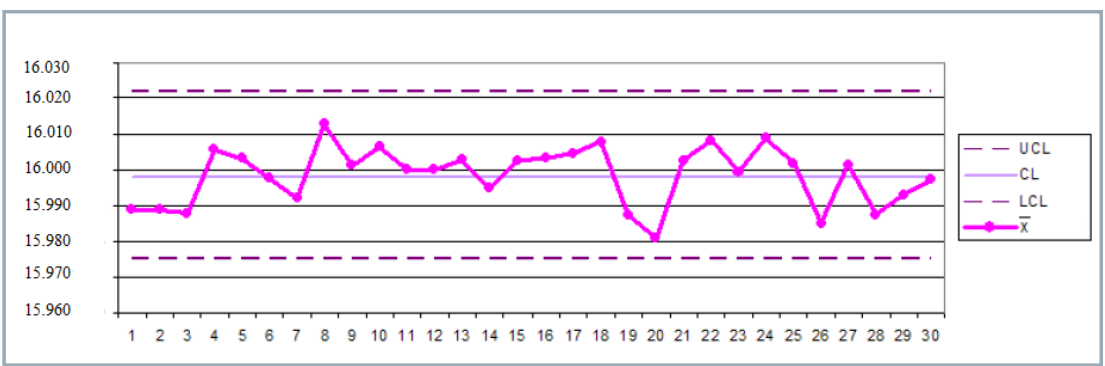

Figure 2 Control chart for average $\bar{X}$

Source: Kudičová, 2012

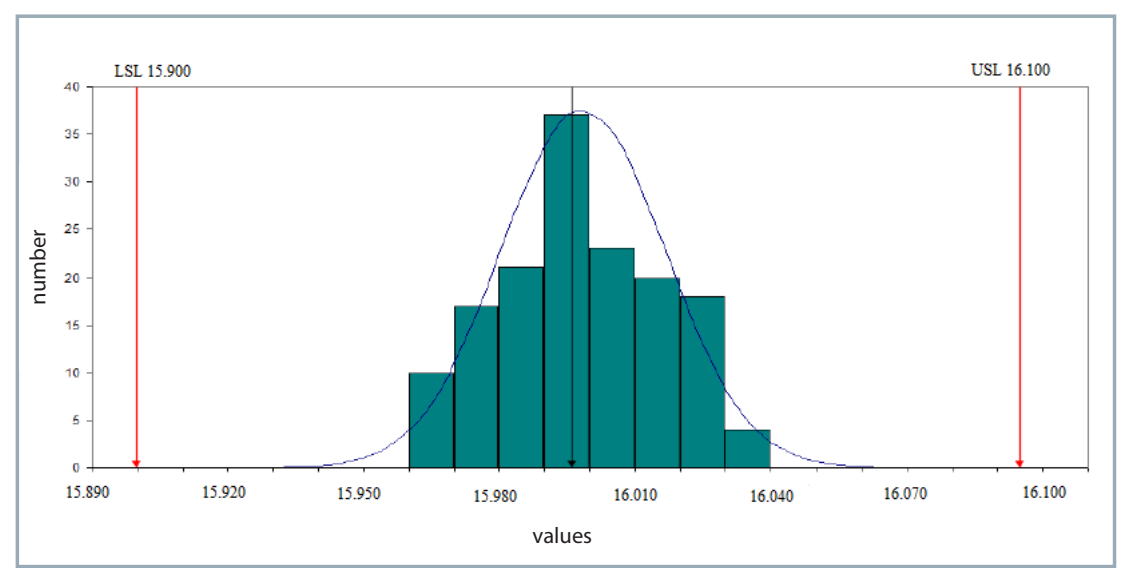

Figure 3 Histogram

Source: Kudičová, 2012 charts for average and range. The lowest capability indices were reached in the screwing process of safety lock $C_{p}=3.14, C_{p k}=2.62$ and backrest plus seat $C_{p}=3.14, C_{p k}=2.7$. The highest capability indices were reached in case of the screwing process of bladder $C_{p}=$ $30.78, C_{p k}=30.78$.

The evaluation of samples production process by $C_{p}$ and $C_{p k}$ indices was also used by Petrík et al. (2008), indicating that both indices are above 1.33 and the process appears capable.

\section{Conclusion}

The injection process capability study in the production of plastic boxes has confirmed the ability of the process to meet the defined requirements for

.

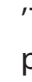
programme into company management structure through integration and utilization of QMS, EMS, HSMS'.

\section{References}

ANDRÁSSYOVÁ, Z. - HRUBEC, J. - KOTUS, M. 2011. Assembly process capability of automotive seats. In Acta Technologica Agriculturae, vol. 14, 2011, no. 3, pp. 74-78. HRUBEC, J. 2001. Riadenie kvality. Nitra : SPU, 2001.

HRUBEC, J. - KRCHNÁK, P. - LESTYÁNSZKA, K. 2014. Inžinierstvo kvality produkcie. Nitra : SPU, 2014.

HRUBEC, J. - VIRČÍKOVÁ, E. 2009. Integrovaný manažérsky systém. Nitra : SPU, 2009.

KORENKO, M. - KAPLÍK, P. - BUJNA, M. PRÍSTAVKA, M. 2013. Statistical process control in automotive industry. In Acta Technologica Agriculturae, vol. 16, 2013, no. 2, pp. 39-42.

KUČEROVÁ, M. - LESTYÁNSZKA, K. 2012. Štatistické metódy kontroly kvality. Trnava : AlumniPress MTF STU, 2012.

KUDIČOVÁ, J. 2012. Posúdenie spôsobilosti procesu výroby výrobku „Box Finger Cot”. Trnava : MTF STU. Diploma thesis, 2012.

PETRÍK, J. - MIKLOŠ, V. 2008. Youden plot in dimensions measurement. In Journal of Engineering. Annals of Faculty of Engineering Hunedoara, vol. 6, 2008, no. 3, pp. 284-293.

PRÍSTAVKA, M. - BUJNA, M. 2013. Use of statistical methods in quality control. In Acta Technologica Agriculturae, vol. 16, 2013, no. 2, pp. 35-38.

PRÍSTAVKA, M. - BUJNA, M. 2014. Monitoring the capability of production equipment in organization. In Acta Technologica Agriculturae, vol. 17, 2014, no. 2, pp. 39-43. 